\title{
EROSION CHANNELS AND CANYONS IN THE CENTRAL SOUTH SWEDISH HIGHLANDS - A SHORT SURVEY
}

\author{
TORSTEN PERSSON
}

\begin{abstract}
PERSSON, TORSTEN 1977: Erosion channels and canyons in the central South Swedish Highlands - a short survey. Bull. Geol. Soc. Finland 49: 11-18.

This paper deals with erosional forms, especially those caused by running water, in the central South Swedish Highlands. The southern area is well peneplained and resembles a lake plateau with gently inclining facet towards the S, SW and SE. Northwards and towards the centre the relief locally increases as the landscape rises.

The southern area is characterized by small erosion channels originating from the last glaciation, but in the central and northern areas there are also large canyons in the bedrock.
\end{abstract}

Torsten Persson, Department of Geography, University of Lund, S-223 62 Lund, Sweden.

\section{Methods}

As a rule this investigation follows the conventional methods that have long been applied in geomorphological research. However, in a landscape that is almost completely covered by thick forest vegetation and lacks up-to-date maps poses some specific problems. My geomorphological field investigations were based upon several local contour maps as well as other planning maps on the scales of $1: 1000$ to $1: 50000$.

Aerial photographs on the scales of $1: 6000$ to $1: 30000$ have to some extent compensated for dearth of satisfactory maps.

Levelling and sounding were used to establish the geomorphological shapes of the canyons and their environment that was the main aim of my investigation. As reported earlier (Persson 1969), sounding is the best method for determining the inner forms of steep canyons.

\section{Localities in central Småland}

Earlier descriptions. In the area there are some inconsequent valley courses that form large and distinct erosion canyons, comparable to ones already known in the surrounding areas (Björnsson 1937, 1940, Nordström and Wendel 1952). In Sweden these are termed 'skura' and 'kurso' (Rudberg 1949), both of which stand for a canyon formed in the bedrock as well as in the Quaternary deposits. As seen from Fig. 1 they occur 


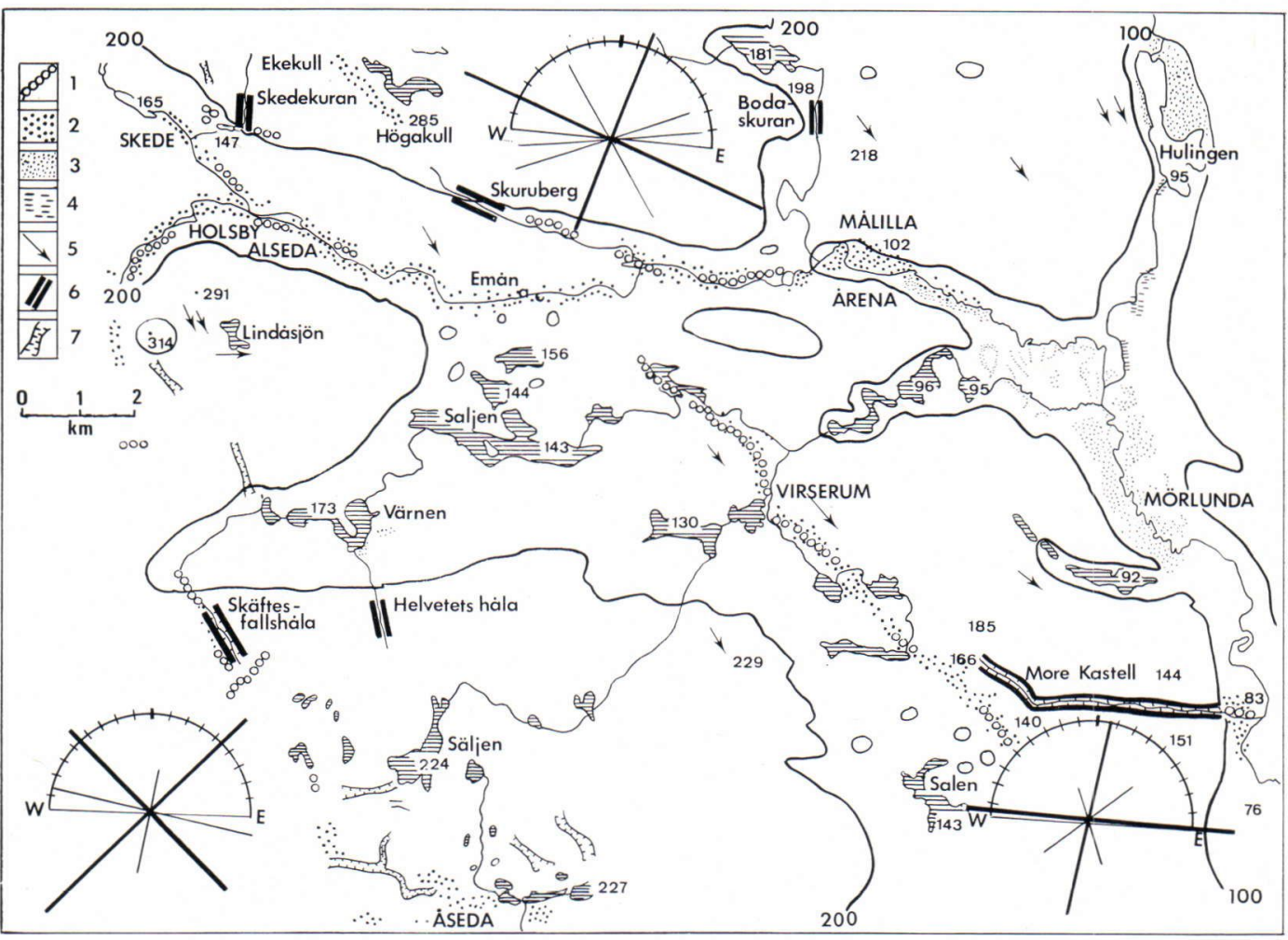

Fig. 1. Survey map of the investigated area. 1. Eskers, 2. Glaciofluvial deposits (plateaus, terraces and irregular fields), 3. Sandy fields, 4. Glacial clay, 5. Striae, 6. Canyons, 7. Small erosion channels. - Contour lines denote 100, 200 and
$300 \mathrm{~m}$ above sea level. The diagrams represent the fracture line in the bedrock at 'Skäftesfalls håla', 'Skurubergs dalgång' and 'More Kastell'. (Godkänd ur sekretessynpunkt för spridning. Statens lantmäteriverk 1975-05-17).

Stretching from east to west for about 10 $\mathrm{km}$, the "More Kastell» is one of the most distinct erosion forms (Fig. 1 and 2). The Emå valley lies here at about $80 \mathrm{~m}$ above sea level and even in the nearest slopes the plateaus reach 100 and 150 metres.

The erosion canyon begins at about $90 \mathrm{~m}$ above sea level with a gentle gradient. Further west it becomes wilder and more winding. Particularly in the spring rapids and falls abound. The bedrock is heterogeneous in composition. There is a longish section of solid 'hälleflinta' with elements of porphyry in the south, and red and grey gneisses bordering it in the north. The $\mathrm{S}$-planes strike from $\mathrm{E}$ to $\mathrm{W}$. The transition between the different kinds of rock is not genetic origin. 


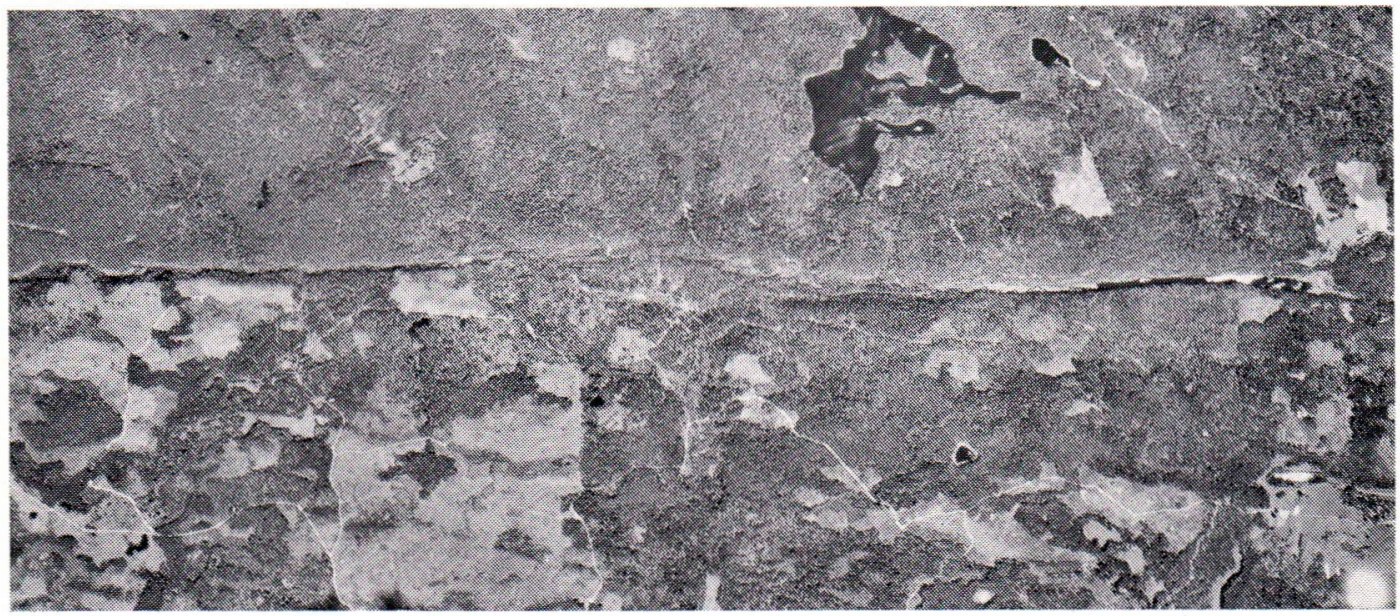

Fig. 2. "More Kastell» is a very distinct cut in the landscape visible for about $10 \mathrm{~km}$ with a clear tectonic and structural origin. However, there are esker trains in the $\mathrm{E}$ and NW, gorge basins and so on indicating water erosion. (Flygfotograferin- gen utförd av rikets allmänna kartverk år 1969 Godkänd för reproduktion och spridning av LMV 1975-09-11. Bilderna godkända för utförsel ur riket med stöd av SFS 1975: 371). distinct, however, and there are some intermediate zones. Characteristic are the heavy fissure lines parallel or subparallel to the canyon or perpendicular to it. Weathering due to frost has crumbled the bedrock walls into small brick-like fragments.

The canyon is quite vertical for about 1 $\mathrm{km}$ near the mouth as well as in the central part. The bedrock walls form a gentle angle to the main direction making constrictions and passes with frequent intervals. This is also true of the rest of the canyon in the tillcovered areas. The number of taluses at the bottom of the canyon below the steep bedrock walls indicates intense frost weathering as do the slides, creeps and chutes. The erosion is concentrated to an area just above the bottom, and has formed hazardous crags and deep caves in the fissure zones beside the talus. Undermining due to fluvial activity at an early stage is revealed in the bedrock.

At Mörtsjöhorv in the east the vertical walls measure $15 \mathrm{~m}$, whereas in the central part they reach a height of more than $20 \mathrm{~m}$.
Thus, the difference in the elevation between the bottom of the canyons and their top is almost $30 \mathrm{~m}$, the water at the bottom included (Fig. 3).

In the inner part, boulders and till cover the bedrock surface, and the depth of the canyon varies from one area to the next. In the $\mathrm{W}$ and $\mathrm{NW}$ the canyon disappears in the forest and swamp terrain about $150 \mathrm{~m}$ above sea level. Ice has had no effect on the canyon at all, but striae trending from the NW on the plateaus indicate the main direction of the glacial flow. The mouth is partly occupied by glaciofluvial sediments that form a central ridge stretching ESE-WNW and consisting of coarse gravel and stones with a lateral sand field in the $\mathrm{N}$ and $\mathrm{S}$. The lower parts have been washed out. At the bottom of the canyon, an esker extends for about 2 $\mathrm{km}$ as a flat and stony ridge. The fine sediments have been washed away and the ridge shows no continuity until NW of the canyon. The canyon 'More Kastell' follows the recent drainage pattern as well as many oth- 

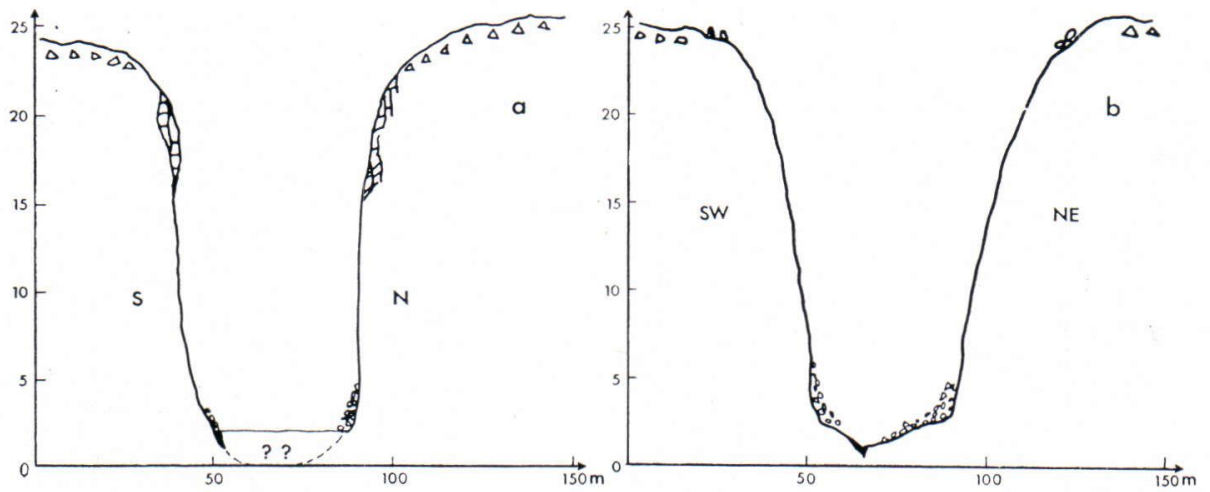

Fig. 3. Cross sections. a. 'More Kastell', b. 'Skäftesfallshåla'.

ers, but there are also some inconsequent valley courses.

The most interesting of these are two canyons in the southern part of the Emå valley, the so-called 'Skäftesfallshåla' (Holst 1885 , p. 50) about $20 \mathrm{~km}$ SSE of Vetlanda, and »Helvetets håla» about $20 \mathrm{~km}$ SE of Vetlanda (Fig. 1). The westernmost canyon, 'Skäftesfallshåla' crosses the water divider between Österkorsberga and Åseda about $290 \mathrm{~m}$ above sea level. The recent small stream through the canyon runs first northwestwards and then eastwards towards lakes Värnen and Saljen before it falls into the Emå River.

The cut in the bedrock descends about 5 $\mathrm{km}$ with vertical bedrock walls, or about $2 \mathrm{~km}$ with subvertical walls. The depth exceeds $30 \mathrm{~m}$ in the gorge - like central part, an indication of fluviatile origin. The average gradient from $\mathrm{SE}$ to $\mathrm{NW}$ is $15 \mathrm{~m} / \mathrm{km}$, but in the steepest parts it exceeds $20 \mathrm{~m} / \mathrm{km}$. The bedrock is granite with a strip of diorite trending from $\mathrm{E}$ to $\mathrm{W}$. The granite is grey and contains plagioclase. In the E it is red with some ortoclase, and forms a ruptured transition zone (cf. Holst 1885, p. 26).

Due SE the Vetlanda esker appears from the $\mathrm{S}$ as a small sequence of winding ridges in the rising terrain. At first it trends to- wards the NE but later towards the NW. However, it does not follow the bottom of the canyon, but runs on the western side about $300 \mathrm{~m}$. Ridges are prominent at that level as is a small sand field indicating the local meltwater level.

The erosion channel is initially only 3 to $4 \mathrm{~m}$ deep in the superficial boulder rich till. It is 50 to $75 \mathrm{~m}$ wide and exhibits typical fluvial erosion form of Quaternary deposits. About $1200 \mathrm{~m}$ further towards the NW the bedrock surface appears on the slopes: red granite towards the $\mathrm{E}$ and grey granite towards the $\mathrm{W}$. The tectonic system follows two main directions trending NW and NNE. The canyon follows alternately the former and the latter tectonic lines, the change in direction being marked by falls and rapids on the thresholds between the two systems. It mainly follows the northwestern tectonic system, which is the most distinct of the two bedrock fragments are detached and an engorged basin indicates intense fluvial erosion. At the mouth of the bedrock canyon there are glacial striae on the upper surface as well as on the vertical bedrock walls due $\mathrm{NW}$. The former trends from the NW and the latter from the NNW. In the falling terrain the esker appears again at about $180 \mathrm{~m}$ above sea level, which is near the end of the canyon at Lake Värnen. 
Close to the Skäftesfallshåla on the same bedrock plateau there is another short, but distinct canyon, the so-called 'Helvetets håla' or 'Trollebo portar' (Fig. 1). Like 'Skäftesfallshåla' it is situated in an isolated area.

The canyon begins about $250 \mathrm{~m}$ above sea level as a small erosion channel, but before long it becomes a deep winding canyon with abundant boulders at the bottom. In the central part there are vertical bedrock walls on both sides of the small recent rills at the bottom.

The bedrock is homogeneous in composition, mainly fine-grained granite of red Växjö type with banks of 10 to $15 \mathrm{~m}$ in size. The bedrock walls are vertical. For a distance of about $500 \mathrm{~m}$ the canyon forms a very narrow gorge similar to the well-known 'Skurugata' (Nordström and Wendel 1952). It is only 35 to $40 \mathrm{~m}$ wide at the top and $25 \mathrm{~m}$ deep. At the bottom there are some typical engorged basins with stagnant water.

One tectonic system trends from SSW to $\mathrm{NNE}\left(\mathrm{N} 10^{\circ} \mathrm{E}\right)$ and another from $\mathrm{SE}$ to $\mathrm{NW}$ $\left(\mathrm{N} 55^{\circ} \mathrm{W}\right)$. The fissure lines have been weathered providing a later target of attack for fluvial erosion, especially since the bedrock has been broken down into small brickshaped fragments. The gorge follows alternately the two tectonic systems. More resistant thresholds occur when the canyon changes direction as has been described elsewhere (Bergsten 1942). The main direction, which is a resultant of the tectonic patterns, trends from SSE to NNW. The erosion channel can be traced for $45 \mathrm{~km}$ down to the eastern part of Lake Värnen $173 \mathrm{~m}$ above sea level.

In contrast to the former canyons, the Skäftesfallshåla has no close connection with glaciofluvial deposits. The influence of water is, however, revealed by the general shape and the mouth. Close to Lake Värnen there is an area of about $1 \mathrm{~km}^{2}$ covered with glaciofluvial deposits originating from the ca- nyon above. Due to the fluvial erosion small erosion channels are also seen close to the main canyon, parallel or subparallel to it.

Glacial erosion has had no influence on the central part of the canyon. There are striae from $\mathrm{N} 30^{\circ} \mathrm{W}$, but the gorge has been too narrow.

\section{Morphogenetical discussion}

Canyons and erosion channels. The canyons within the area are of a complicated origin. There is a structural bedrock pattern, which was the basis of the erosion before Quaternary time. Sometimes the canyon and the erosion valleys follow the bedrock system almost completely as does 'More Kastell'. The same is true of others, e.g. 'Skäftesfallshåla'; both are marked by abundant thresholds and narrow passages where the absence of fissure lines indicates that the bedrock was more resistant. The direction of the canyon 'Helvetets håla' alternates from one to the other, the change between them being marked by resistant bedrock lines with rapids and falls.

In a discussion on origin, the position in the terrain is of great interest. 'Skäftesfallshåla' is situated at the pass between two small peaks, which represent a col guly (Mannerfelt 1945).

'Helvetets håla' is a typical cut in the bedrock plateau as is seen in many places elsewhere above all in the Scanian horst lines (Bergsten 1942, Behrens 1953, Svensson 1970).

Many of the canyons have served as outlets of glacial lakes and some may even originate from the last phases of the last glaciation.

'Skäftesfallshåla' has been subject to glacial erosion, but only in the proximal mouth. As a rule, however, the ice tended to leave the central parts of the canyons intact, because they are so narrow (Rudberg 1949, 


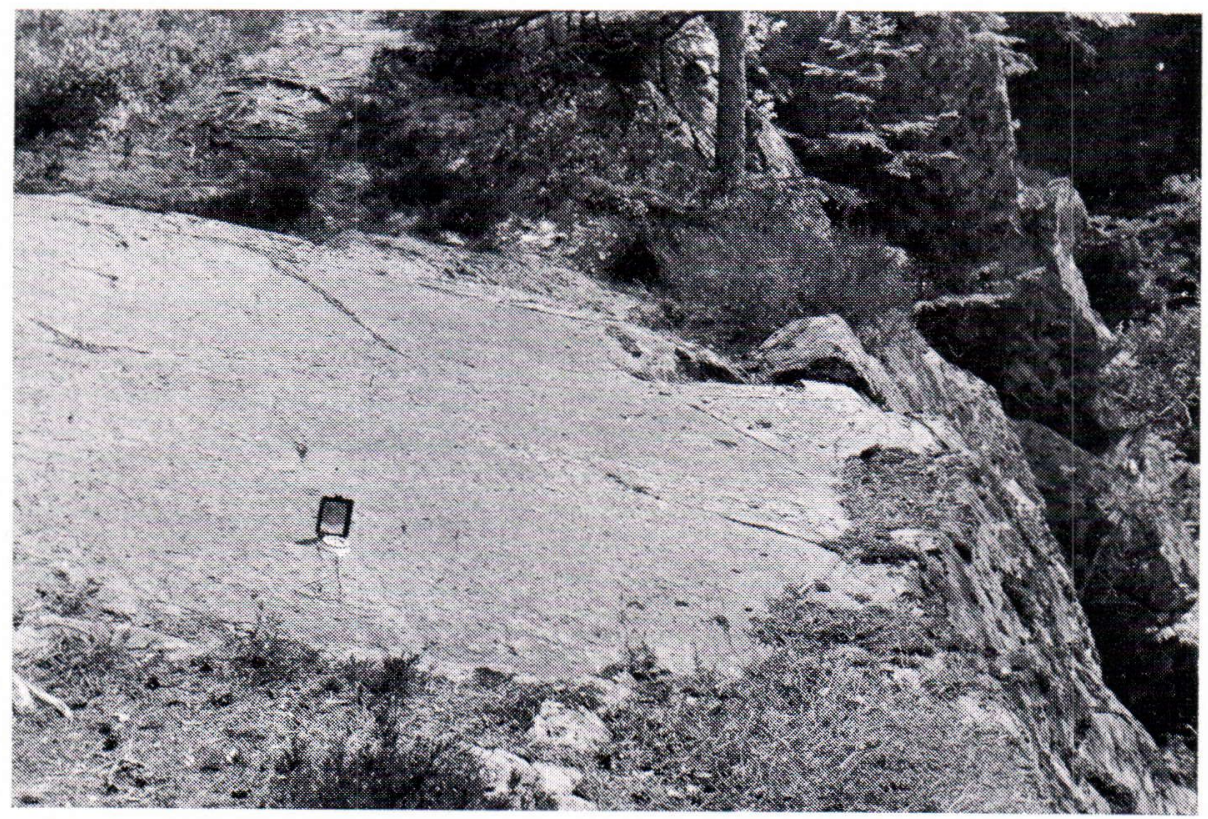

Fig. 4. Glacial bedrock surface close to the fracture line at 'Helvetets håla'. The ice has not influenced the canyon in this place. The striae trend from $\mathrm{N} 30^{\circ} \mathrm{W}$.

Markgren 1962) (Fig. 4). In the interpretation both the time of erosion and the morphological agencies must be considered. It is not known whether the huge erosion canyons are a result of recent erosion or still older. During postglacial time there has not been enough water or any other agency to form such cuts in the bedrock or in the till. Slips, slides and solifluction as well as postglacial weathering have only succeeded in reducing the relief (Rudberg 1949, Mattsson 1962, Markgren 1963).

When erosion channels pass through till, there is no doubt that running water has been the erosional agency. On vertical bedrock surfaces, however, indications of running water are rare, partly as a result of, postglacial weathering. Erosion channels parallel or subparallel to the huge canyons as well as some areas with bedrock walls polished by water indicate water erosion. Plunged pools and undermining, lend further support to this interpretation.
They are also generally accompanied by glaciofluvial courses. The meltwater has found its way to the ice sole, with a tremendous force on the steep slopes or at the pass points. During the final stage of glacial recession the ice became inactive and the meltwater deposited material under the ice parallel to the eskers or in other directions.

On proximal slopes, the water rushed down as engorged chutes. Hydrostatic pressure lent force to the water and, with seasonal variations, the erosion continued for a long time. Even the canyon at Trollebo may originate from melting water. On the plateaus towards the $\mathrm{W}$ and SW there are many ablation moraines in front of the ice edge, from where the meltwater courses dropped towards the valley bottom about $100 \mathrm{~m}$ below. There are no eskers close to the canyon, instead there is a wash-out plane of gravel and stones, which originates from the canyon close to Lake Värnen and indicates transport from $\mathrm{S}$ to $\mathrm{N}$ in a chute channel. 
However, the active phase was not probably confined to the time of a subglacial drainage pattern. The meltwater formed glacial lakes in front of the ice and between the rising plateaus in the south.

One example among many is the glacial lake of Solgen with a water level of about $10 \mathrm{~m}$ above the recent level and with connections to three erosion canyons (Persson 1969, p. 94, 95).

One remaining problem is how to distinguish all the more or less ephemeral ice lakes in the area.

Another question is whether the canyons were formed during the last glaciation, the glacial periods, or whether they are of preglacial origin. The latter is suggested by the location of the valleys along fracture zones in the bedrock surface. These were weathered and eroded during a long period of preglacial time, but very little is known about the bedrock surfaces, except for the remaining kaoline weathering.
If we accept the canyons as Quaternary forms they were probably mainly formed during periglacial time by melting water during the final periods of the glaciations. In the meantime weathering, slides and slips loosened the bedrock fragments along the fissure lines.

How much can we ascribe to the latest glaciation? The answer to that will perhaps be found through an estimation of the amounts of the sediments deriving from the canyons and channels. However, as a rule, there sediments are nearly always mixed with glaciofluvial drift. One exception is the canyon at Trollebo, where the sediments close to Lake Värnen emanate from the canyon. Abundant sediments were spread over the surroundings during deglaciation, but there is no simple correlation between the deposits and the canyons indicating that the canyons originate from the last glaciation only.

\section{References}

Behrens, S. (1953) Morfometriska, morfogenetiska och tektoniska studier av de nordvästskånska urbergsåsarna. Med särskild hänsyn till Kullaberg. Medd. Lunds Univ. Geogr. Inst. Avh. 24. $254 \mathrm{p}$.

Bergsten, K. E. (1942) Forsakar. En morfologisk detaljundersökning i Oóstra Skåne. Svensk Geogr. Årsbok 18: 78-92.

Björnsson, S, (1937) Sommen-Åsundenområdet. En geomorfologisk studie. Medd. Lunds Univ. Geogr. Inst. Avh. 4. 234 p.

- (1940) Tre klippkanjoner. I Från Sommabygd till Vätterstrand. $4 \mathrm{p}$.

- (1953) Drumlinbildningar i Sommen-Åsundenområdet. Svensk Geogr. Årsbok 29.

Björklund, C. (1965) Isälvsavlagringar och issjöar i Hässleholmstrakten. Manuskr. Lunds Univ. Geogr. Inst.

Friberg, N. (1957) Skvalrännorna vid RumskullaHult. Ymer 77: 81-107.
Holst, N. O. (1885) Beskrifning till kartbladet Hvetlanda. Sver. Geol. Unders. Ser Ab, No. 8

Hoppe, G. (1952) Några glacifluviala erosionsrännor på Sydsvenska höglandet. Geol. Fören. Stockholm Förh. 74(2).

Johnsson, G. (1956) Glacialmorfologiska studier i Södra Sverige. Medd. Lunds Univ. Geogr. Inst. Avh. 30. 407 p.

Mannerfelt, C M:son. (1945) Några glacialmorfologiska formelement och deras vittnesbörd om inlandsisens avsmältning i svensk och norsk fjällterräng. Geogr. Ann. 27. 245 p.

Markgren, $M$. (1962-63) Detaljmorfologiska studier i fast berg och blockmaterial. Geomorfologisk studie i Fennoskandia med Skåne. I Vittringsprocesser och vittringsformer. II Residuala blockfält samt polygena blockfält. Medd. Lunds Univ. Geogr. Inst. Avh. 43. 92.

Mattsson, $A$. (1961) Preglacialt anlagda dalstråk på de skånska horstarna. Svensk Geogr. Årsbok 37: $215-218$. 
- (1962) Morphologische Studien in Südschweden und auf Bornholm über die nichtglaziale Formenwelt der Felsenskulptur. Medd. Lunds Univ. Geogr. Inst. Avh. 39. 357 p.

Munthe, H. (1940) Om Nordens, främst Baltikums, senkvartära utveckling och stenåldersbebyggelse. Kungl. Svenska Vetenskapsakad. Handl. 19(1), $242 \mathrm{p}$.

Nilsson, E. (1942) Gotiglaciala issjöar i södra Sverige. Geol. Fören. Stockholm Förh. 64: 143-160.

Nilsson, E. (1953) Om södra Sveriges senkvartära historia. Geol. Fören. Stockholm Förh. 75: $155-246$.

- (1958) Issjöstudier i södra Sverige. Geol. Fören. Stockholm Förh. 80: 166-186.

- (1960) Södra Sverige i senglacial tid. Geol. Fören. Stockholm Förh. 82: 134-150.

- (1968) Södra Sveriges senkvartära historia. Kungl. Svenska Vetenskapsakad. Handl. IV, Ser 12, I, $100 \mathrm{p}$.

Nordström, Wendel. (1952) Skurugata. En klippkanjon på sydsvenska höglandet. Svensk Geogr. Årsbok 28: 30-35.

Persson, T. (1969) Skuror och andra erosionsrännor inom Smålands högland. Svensk Geogr. Årsbok 45: 73-98.
- (1971) Några HK-indikationer i södra Sverige. Svensk Geogr. Årsbok 47: 73-91.

- (1972) Geomorphological studies in the SouthSwedish highlands. With special reference to the glacial forms. Medd. Lunds Univ. Geogr. Inst. Avh. 66. 67 p.

Rudberg, S. (1949) Kursudalar i Norrbotten, en preliminär översikt. Geol. Fören. Stockholm Förh. 71: 442-494.

Rydström, S. (1964) Kvartärgeologiska studier inom Värend, södra Kronobergs län. Manuskr. Lunds Univ. Kvartärgeol. Inst.

- (1971) The Värend District during the last glaciation. Geol. Fören. Stockholm Förh. 93: $537-552$.

Svensson, H. (1970) Dalgångar i Hallandsåsen och deras funktion i landskapsbildningen. Svensk Geogr. Årsbok 46: 186-196.

Tell, L. (1963) Preliminär katalog över grottor i Sverige. Ark. för svensk grottforskning 3. 72 p. Norrköping.

Tullström, H. (1954) Kvartärgeologiska studier inom Rönneåns dalbäcken i Nordvästra Skåne. Sver. Geol. Unders. Ser C (530). 73 p.

Manuscript received, September 15, 1975. 